\title{
Environmental Impacts Evaluation of Sorbitol Production from Glucose
}

\author{
Rifkah Akmalina $\mathrm{a}^{*}$ \\ ${ }^{a}$ Department of Chemical Engineering, Universitas Pamulang, Jl. Surya Kencana No. 1 Pamulang Barat, \\ Tangerang, 15415, Indonesia
}

Article history:

Received March $6^{\text {th }} 2019$ Revised March $26^{\text {th }} 2019$ Accepted March $30^{\text {th }} 2019$ Online March $31^{\text {st }} 2019$

\begin{abstract}
A life cycle assessment (LCA) has been performed on sorbitol production from glucose, which aims to quantify and evaluate the environmental impacts produced from the process. SuperPro Designer software was employed to perform the process simulation, while SimaPro was used to quantify the LCA. The potency of global warming, acidification, eutrophication, photochemical oxidants creation, abiotic depletion, and ozone layer depletion were evaluated. A gate-to-gate LCA study of sorbitol production showed that global warming potential (GWP) had the largest impact on the environment with the value of $3.551 \mathrm{~kg} \mathrm{CO} 2 \mathrm{eq} / \mathrm{kg}$ sorbitol. Glucose and electricity consumption were known as two major contributors to GWP, and hydrogen reactor was the main consumer of electricity. The use of glucose was responsible for more than $50 \%$ of the total environmental impact in each category. Performing heat integration in sorbitol processing is highly recommended for a gate-to-gate system to reduce energy demand, thus decreasing the environmental impacts. Therefore, this LCA study may be applied to perform a sustainable improvement in the sorbitol production process.
\end{abstract}

Keywords: sorbitol; life cycle assessment; global warming potential

\section{Introduction}

Sorbitol is a sugar alcohol which has a molecular formula of $\mathrm{C}_{6} \mathrm{H}_{14} \mathrm{O}_{6}$. As a sweetener, sorbitol has been found useful in sugar-free and reduced-sugar products because it has the relative sweetness of $60 \%$ compared to sucrose with only 2.6 calories per gram (Food Insight, 2009; Silveira and Jonas, 2002). In the food industry, sorbitol is also used as a moisturizer, texturizer, and softener for production of gums, candy, and many other food products (Silveira and Jonas, 2002). According to Marques et al. (2016), Indonesia occupies the second largest producer of sorbitol and starch sweeteners after China, and the Asia Pacific becomes the main area for sorbitol distribution. It can be expected that the demand for sorbitol will grow more extensively so that the production of sorbitol will hold great potential in food and chemical industries that develop rapidly.

In general, sorbitol can be produced chemically or biotechnologically, but the chemical process via catalytic hydrogenation of glucose is the process that has been globally applied on an industrial scale. Based on Silveira and Jonas (2002), about $80 \%$ of sorbitol production is performed in batch mode and catalyzed by Raney nickel. The chemical process of sorbitol production which generally consists of hydrogenation of glucose and several

${ }^{*}$ Corresponding Author:

Email: dosen02262@unpam.ac.id steps of purification will result in environmental impacts. Every step of the process may generate emission that can be harmful to the environment. Hence, a reliable environmental assessment should be conducted to identify the environmental impact of sorbitol production.

Life cycle assessment (LCA) is a quantified analytical tool extensively used to estimate the environmental impacts and burdens of any product system over its entire life cycle, starting from obtaining raw material, distribution, production of intermediate and main products, and final disposal of waste (Fiorentino et al., 2014; Guinee, 2006). This method is important to determine which process that significantly affect the environment. However, there are a few LCA studies that discuss the environmental impact of a sweetener production process. Gerbrant (2014) examined the life cycle of xylitol production from hemicellulose residues besides its process design and techno-economic, while Hafyan et al. (2019) assessed a sustainable xylitol production from empty fruit bunch. Lestari et al. (2013) performed a life cycle assessment of sugar from sugarcane based on a case study in Indonesia. Liquid glucose as a raw material of sorbitol production was also assessed for its environmental impacts as reported by An and Katrien (2015). Meanwhile, for sorbitol itself, there is no research found that discuss the LCA. It is important to figure out the impacts of sorbitol 
production in addition to xylitol, sucrose, and other sweeteners so that the comparison could be made to find the most environmentally friendly process.

In this study, LCA was conducted to quantify and evaluate the environmental impacts of sorbitol production from glucose. The analysis included only the main production process; from glucose to dried sorbitol without distribution process and waste disposal (gate-to-gate scope). The production process of sorbitol was simulated using SuperPro Designer, while the LCA was calculated using SimaPro software. The potency of global warming, acidification, eutrophication, photochemical oxidants creation, abiotic depletion, and ozone layer depletion were evaluated so that the major emission contributors to the environment could be known. This assessment is also important to prevent pollutant transfer caused by sorbitol industrial activities. Therefore, there is a possibility to develop sorbitol production process based on sustainable improvement.

\section{Research Method}

SuperPro Designer software was employed to perform process simulation of sorbitol production. Process flow diagram and operating conditions available in SuperPro was used for simulation. Simulation of the entire process resulted in mass balance and energy balance, which was further used to apply LCA method, together with emission data.

A gate-to-gate LCA for sorbitol production was quantified using SimaPro software. The indirect emission data needed for LCA calculation was also obtained from the SimaPro database. The LCA methodology is divided into four steps as defined by ISO standards (ISO 14040):

- Goal and scope definition: defining the objective of the study and the boundaries of the system.

- Inventory analysis: collecting input and output data of the product system (including energy, resources, and emissions to air and water).

- Impact assessment: conversion of material flows (based on inventory) into environmental impacts.

- Interpretation: interpreting the results to give recommendations to improve the environmental performance of the product.

\subsection{Process Description}

The process of sorbitol production used in this study was the chemical process. According to Ochoa-Gómez and Roncal (2017), hydrogenation of aqueous solutions of glucose using metal-based catalysts was a well-established process, while the biotechnology is still challenging in terms of effective strains and optimum culture conditions for better production (Marques et al., 2016). The production process of sorbitol and the operating conditions were adapted from SuperPro database as described below.

Glucose solution with a concentration of $95 \%$ (dry solids basis) is initially mixed with water until reach a final water content of around $50 \%$. This glucose syrup then enters the hydrogenation reactor, followed by hydrogen. The hydrogenation process is operated in batch mode and catalyzed by RaneyNickel. Raney-Nickel is the most-used catalyst for industrial sorbitol production, and the nickel-based has a low cost compared to other suitable metalbased catalysts (Ochoa-Gómez and Roncal, 2017). The hydrogenation reaction is carried out at a temperature range of $120-130^{\circ} \mathrm{C}$ and pressure of 60 bar. Cooling water is used to maintain reactor temperature because of its exothermic reaction. All unreacted hydrogen is removed with nitrogen gas sweep.

The converted syrup is then cooled to $52^{\circ} \mathrm{C}$ and flowed into batch ion exchangers to remove salts and dissolved metal catalyst (Ochoa-Gómez and Roncal, 2017) contained in syrup product. Cation resin of ion exchanger is regenerated using $\mathrm{HCl}$, while the anion resin is regenerated using $\mathrm{NaOH}$. Syrup exiting from ion exchangers is then heated to $72^{\circ} \mathrm{C}$ and passed through granular activated carbon (GAC) column to remove color and odors. After that, the syrup is fed into an evaporator to be concentrated, so that the $70 \%$ sorbitol solution is obtained. The vapor condensate of the evaporator is cooled and recycled to be reused in ion exchangers and GAC column. Finally, the sorbitol solution is dried in a spray drier to get dry sorbitol with a concentration of $95 \%$.

\subsection{Goal and Scope Definition}

The goal of this study is to evaluate and quantify the environmental impacts of sorbitol production from glucose. The function of the system is the production of dry sorbitol, and the functional unit is $1 \mathrm{~kg}$ of sorbitol 95\%. All inputs and outputs, e.g. feedstock, emissions levels, and consumption of energy are based on this functional unit.

A gate-to-gate assessment was carried out which included preparation of glucose as raw material, hydrogenation process, and product purification until dried sorbitol was obtained (Figure 1). The transportation process and waste treatment were not included because of the lack of information and data.

\subsection{Inventory Analysis}

In this study, the inventory analysis includes the quantities of input and output materials of the overall sorbitol production process, energy consumption, and emission released to the environment. All collected data is then known as life cycle inventory (LCI), which is further associated with the functional unit as defined before. 


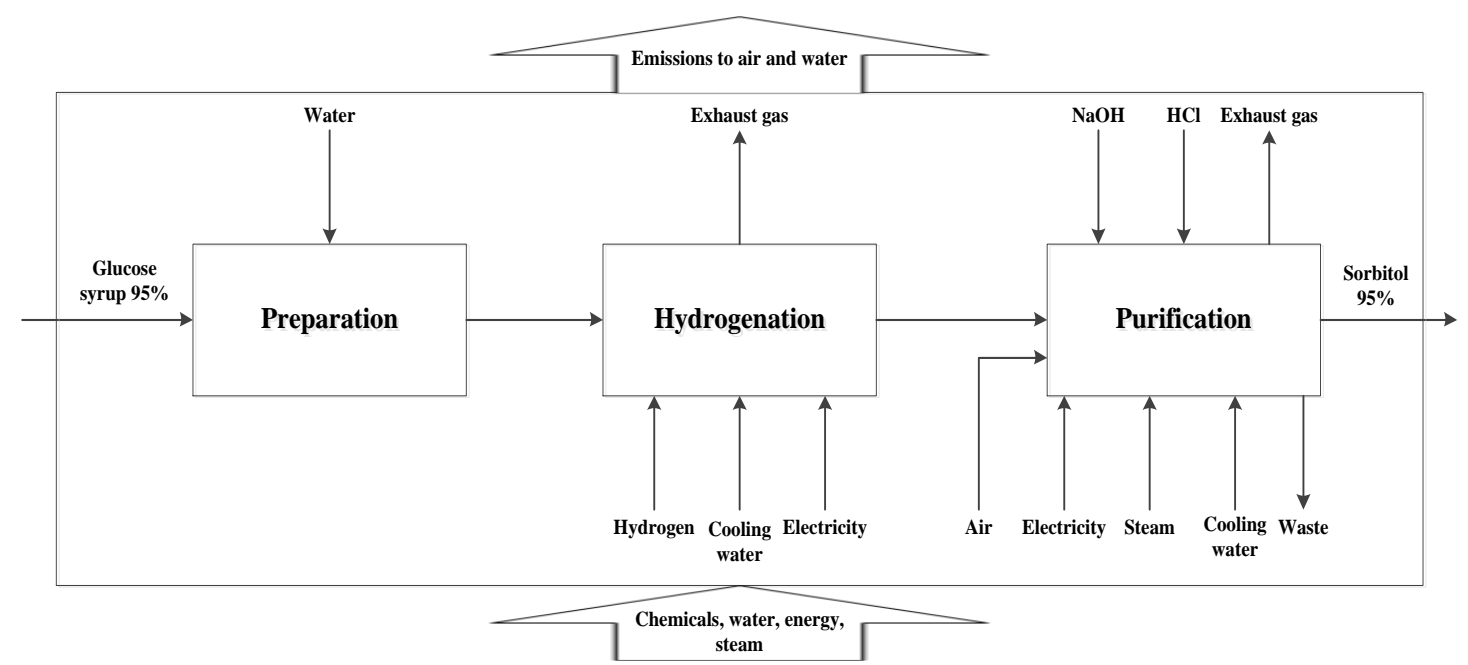

Figure 1. System boundary of sorbitol production

Table 1. Inventory data for LCA of sorbitol

\begin{tabular}{|c|c|c|c|c|c|}
\hline \multicolumn{3}{|l|}{ Inputs } & \multicolumn{3}{|l|}{ Outputs } \\
\hline Item & Amount & $\begin{array}{l}\text { Unit (per kg of } \\
\text { sorbitol) }\end{array}$ & Item & Amount & $\begin{array}{l}\text { Unit (per kg of } \\
\text { sorbitol) }\end{array}$ \\
\hline \multicolumn{6}{|l|}{ Preparation } \\
\hline Glucose syrup & 1.33 & $\mathrm{~kg}$ & & & \\
\hline Water & 0.31 & $\mathrm{~kg}$ & & & \\
\hline Hydrogenation & & & Hydrogenation & & \\
\hline Hydrogen & 0.012 & $\mathrm{~kg}$ & Exhaust gases & & \\
\hline Cooling water & 570.28 & $\mathrm{~kg}$ & $\mathrm{O}_{2}$ & 0.0008 & $\mathrm{~kg}$ \\
\hline \multirow[t]{5}{*}{ Electricity } & 0.74 & $\mathrm{~kW}$ & $\mathrm{~N}_{2}$ & 0.0297 & $\mathrm{~kg}$ \\
\hline & & & $\mathrm{H}_{2}$ & 0.0013 & $\mathrm{~kg}$ \\
\hline & & & $\mathrm{H}_{2} \mathrm{O}$ & 0.0147 & $\mathrm{~kg}$ \\
\hline & & & Organic acids & $1.65 \mathrm{E}-05$ & $\mathrm{~kg}$ \\
\hline & & & Sorbitol & $3.99 \mathrm{E}-07$ & $\mathrm{~kg}$ \\
\hline Purification & & & Purification & & \\
\hline $\mathrm{NaOH}$ & 0.031 & $\mathrm{~kg}$ & Product & & \\
\hline $\mathrm{HCl}$ & 0.009 & $\mathrm{~kg}$ & Sorbitol & 1 & $\mathrm{~kg}$ \\
\hline Air & 1.69 & $\mathrm{~kg}$ & Exhaust gases & & \\
\hline Electricity & 0.027 & $\mathrm{~kW}$ & $\mathrm{~N}_{2}$ & 1.296 & $\mathrm{~kg}$ \\
\hline Steam & 0.95 & $\mathrm{~kg}$ & $\mathrm{O}_{2}$ & 0.394 & $\mathrm{~kg}$ \\
\hline \multirow[t]{12}{*}{ Cooling water } & 33.24 & $\mathrm{~kg}$ & $\mathrm{H}_{2} \mathrm{O}$ & 0.341 & $\mathrm{~kg}$ \\
\hline & & & Waste & & \\
\hline & & & $\mathrm{HCl}$ & 0.0015 & $\mathrm{~kg}$ \\
\hline & & & Higher polyols & $5.05 \mathrm{E}-06$ & $\mathrm{~kg}$ \\
\hline & & & Maltitol & $4.52 \mathrm{E}-05$ & $\mathrm{~kg}$ \\
\hline & & & Maltotritol & $3.30 \mathrm{E}-05$ & $\mathrm{~kg}$ \\
\hline & & & Organic acids & 0.0018 & $\mathrm{~kg}$ \\
\hline & & & $\mathrm{NaOH}$ & 0.0049 & $\mathrm{~kg}$ \\
\hline & & & Soluble protein & 0.00013 & $\mathrm{~kg}$ \\
\hline & & & Solubles & $6.57 \mathrm{E}-05$ & $\mathrm{~kg}$ \\
\hline & & & Sorbitol & 0.0018 & $\mathrm{~kg}$ \\
\hline & & & Water & 0.278 & $\mathrm{~kg}$ \\
\hline
\end{tabular}

Table 1 above shows the inventory data needed for carrying out the LCA, based on $1 \mathrm{~kg}$ of sorbitol.

\subsection{Impact Assessment}

The inventory analysis is then followed by characterization of environmental impacts, as part of the life cycle impact assessment (LCIA). Based on LCIA standard methodology, classification and characterization phase are mandatory, while normalization and weighting are optional (ISO 14040). In this LCA study, LCIA phase was performed only for classification and 
characterization. The LCIA was calculated using SimaPro software, then the results were verified manually using Ms. Excel.

There were six impact categories evaluated in this study: global warming potential (GWP), acidification potential (AP), eutrophication potential (EP), photochemical ozone creation potential (POCP), abiotic depletion potential (ADP), and ozone layer depletion potential (ODP) According to Guinee (2006), the potential value of each impact category were calculated using basic equations given below.

$$
\begin{aligned}
& G W P=\Sigma G W P_{a, i} \times m_{i} \\
& A P=\Sigma A P_{i} \times m_{i} \\
& E P=\Sigma E P_{i} \times m_{i} \\
& P O C P=\Sigma P O C P_{i} \times m_{i} \\
& A D P=\Sigma A D P_{i} \times m_{i} \\
& O D P=\Sigma O D P_{i} \times m_{i}
\end{aligned}
$$

Equation (1) to equation (6) are explained as follow:

- $m_{i}$ denotes quantities of substance $i$ emitted (in $\mathrm{kg}$ )

- Superscript $i$ attached to each impact category denotes the impact for substance $i$

- GWP is expressed in $\mathrm{kg} \mathrm{CO}_{2}$ eq

- $\quad \mathrm{AP}$ is expressed in $\mathrm{kg} \mathrm{SO}_{2}$ eq

- $\mathrm{EP}$ is expressed in $\mathrm{kg} \mathrm{PO}_{4}{ }^{3-}$ eq

- $\mathrm{POCP}$ is expressed in $\mathrm{kg} \mathrm{C}_{2} \mathrm{H}_{4}$ eq

- $\mathrm{ADP}$ is expressed in $\mathrm{kg} \mathrm{Sb}$ eq

- ODP is expressed in kg CFC-11 eq

For LCA study involving normalization and weighting, Baumann and Rydberg (1994) stated a correlation between environmental load, indices, and total impact of any product as written in equation (7). Regarding to the equation, they also mentioned three of methods that can be used to do weighting analysis: the ecological scarcity (ECO), environmental theme (ET), and environmental priority strategies (EPS). Each method has different indexes, and commonly the comparison between one method and the other is also performed.

$$
T I(\text { method })=\sum_{j}\left(L I_{j}(\text { method }) x \operatorname{load}_{j}\right)
$$

- $\mathrm{TI}($ method $)=$ total impact as calculated according to the method used

- $\mathrm{LI}_{\mathrm{j}}($ method $)=$ load index $j$ according to the method used

- $\operatorname{Load}_{\mathrm{j}}=$ environmental load of $j$ of the product (mass unit)

- $j=$ substance that causes environmental impact

\subsection{Interpretation}

Based on the results of LCI and LCIA analysis, there are several issues need to be identified: (1) amount of emission released from sorbitol production process, (2) emission inventory and process identification that significantly resulted in environmental impacts, and (3) potency of environmental impacts category (GWP, AP, EP, POCP, ADP, and ODP) caused by sorbitol product.

\section{Results and Discussion}

\subsection{Life Cycle Inventory}

Sorbitol production was classified into three main processes: preparation, hydrogenation, and purification (see Figure 1). For LCA calculation, materials used in the process was simplified to the inputs and outputs flow only, including electricity and heat needed.

For electricity input, the calculation was based on electricity voltage transformation from high to medium voltage. Hydrogenation reactor and pump are the equipment that used electricity, in which the usage in hydrogenation step is greater than in purification because of the power for agitation. All energy for heating in the purification process are generated from steam, meanwhile, there is no heat entered the hydrogenation process because it is an exothermic process that releases heat to carry out the reaction.

The emission produced during the process were distinguished into emission to air and emission to water. Hydrogenation and purification process release exhaust gases that mainly contain hydrogen, nitrogen, oxygen, and water vapor. Moreover, the purification process also produces waste from ion exchanger and GAC column as emission to water.

\subsection{Life Cycle Impact Assessment}

The LCIA results in this study were based on the production of $1 \mathrm{~kg}$ of sorbitol $95 \%$. Six impact categories considered for the environmental characterization (GWP, AP, EP, POCP, ADP, and ODP) are the most common and well-established categories for LCA study. They were evaluated according to the CML method in SimaPro software. By performing an impact assessment, the parts of a sorbitol life cycle that contributes the largest environmental impact can be determined (Lestari et al., 2013).

Table 2 shows the results of impact assessment for each impact category, which can be seen that the highest potential of environmental impact is global warming or greenhouse gas (GHG) emission, with the impact value of $3.551 \mathrm{~kg} \mathrm{CO} 2 \mathrm{eq} / \mathrm{kg}$ sorbitol. This value is relatively high compared to the study of sucrose production reported by Renouf et al. (2008), in which the GHG emission of sucrose from corn was $0.95 \mathrm{~kg} \mathrm{CO}_{2} \mathrm{eq} / \mathrm{kg}$ sucrose. One factor that causes the difference is feedstock used in producing the 
sweetener, particularly the feedstock production, as stated by Gerbrandt (2014). In addition, the value of GWP in this study is slightly different from the result of xylitol production studied by Hafyan et al. (2019). They reported the GWP of $3.83 \mathrm{~kg} \mathrm{CO} 2 \mathrm{eq} / \mathrm{kg}$ xylitol, in which the heat consumption became the major contributor. In some cases, xylitol production from lignocellulosic requires more processes in its preparation step (e.g. xylan extraction and hydrolysis) compared to the sorbitol production. Nevertheless, having a longer process is not always causing a larger impact. There are other factors that influence the environment more significantly, for instance, the energy (heat and electricity) consumption.

Table 2. Impact assessment from production of $1 \mathrm{~kg}$ of sorbitol

\begin{tabular}{lrl}
\hline $\begin{array}{l}\text { Impact } \\
\text { category }\end{array}$ & $\begin{array}{r}\text { Total impact of } \\
1 \mathrm{~kg} \text { of sorbitol }\end{array}$ & Unit \\
\hline GWP100a & 3.551 & $\mathrm{~kg} \mathrm{CO}_{2} \mathrm{eq}$ \\
AP & $1.81 \times 10^{-2}$ & $\mathrm{~kg} \mathrm{SO}_{2} \mathrm{eq}$ \\
EP & $1.31 \times 10^{-2}$ & $\mathrm{~kg} \mathrm{PO}_{4}{ }^{3-} \mathrm{eq}$ \\
POCP & $6.25 \times 10^{-4}$ & $\mathrm{~kg} \mathrm{C}_{2} \mathrm{H}_{4} \mathrm{eq}$ \\
ADP & $1.51 \times 10^{-5}$ & $\mathrm{~kg} \mathrm{Sb} \mathrm{eq}^{-1}$ \\
ODP & $2.26 \times 10^{-7}$ & $\mathrm{~kg} \mathrm{CFC}-11 \mathrm{eq}$ \\
\hline
\end{tabular}

All assessed impact categories are then broken down into the form of process contribution to the individual impact categories (Figure 2). These results are simply used to determine the processes that give the highest impact on the performance of sorbitol life-cycle (Peters et al., 2015). In general, the use of glucose is the greatest contributor to each impact category. It is responsible for more than $50 \%$ of the total environmental impact in each category. An and Katrien (2015) reported that the agricultural phase for preparing liquid glucose became the most significant contribution to the environmental impact categories in major. It was stated that for climate change impact category, for example, the growing of raw materials released $511 \mathrm{~kg} \quad \mathrm{CO}_{2}$ equivalents, while the processing resulted in $332 \mathrm{~kg} \mathrm{CO}_{2}$ equivalents. Therefore, the high contribution of glucose is certainly caused by its preparation and production process before used for producing sorbitol.

A high value of GWP impact (as shown in Table 2 ) is mainly contributed by glucose $(54 \%)$. The most effective way to reduce the effect of glucose is performing an improvement for the glucose production process, especially in raw materials cultivation stage. Unfortunately, that method is appropriate only for LCA study that discusses at least a cradle-to-gate system. Thus, for a gate-to-gate system, the effort to mitigate GHG emission can be done on the other components.

Besides the use of glucose, electricity consumption also causes a high GWP, followed by the use of steam. They contribute $35 \%$ and $9 \%$ of total GHG emissions, respectively. The hydrogenation process is responsible for $96.5 \%$ of the overall electricity demands of the system, or in other words, the hydrogenation reactor is the main consumer of electricity. The high electricity demand of the reactor is caused by its heating utility $(0.734$ $\mathrm{kW}$ for $1 \mathrm{~kg}$ of sorbitol) to initiate the reaction. In this sense, the easiest way to reduce electricity consumption is by decreasing the final temperature in the heating process before the reaction is carried out.

Similar to GWP, glucose and electricity become two major causes of POCP. However, the values are not too significant compared to GWP because the total impact of POCP is only $6.25 \times 10^{-4} \mathrm{~kg} \mathrm{C}_{2} \mathrm{H}_{4}$ eq per $\mathrm{kg}$ sorbitol produced. AP and EP have slightly difference in the total impact value, which means the potential of acidification and eutrophication to the environment is almost equal. The differences lie on the contribution of each component, in which the use of glucose gives more impact in eutrophication. Meanwhile, the effect of electricity and steam consumption in EP is lower than AP. Hydrogen, $\mathrm{NaOH}, \mathrm{HCl}$, and water contribute only a minor share to AP and EP.

Glucose also becomes the principal contributor to abiotic depletion, even the contribution attains $97 \%$ of its total impact. As a result, the other components give only a minor portion of ADP. On the other hand, steam and $\mathrm{NaOH}$ occupy the second and third largest contributor to ODP after glucose, with a percentage of $12 \%$ and $10 \%$ respectively. Although the emission generated from steam consumption is not too substantial, reducing the amount of steam for heating process or performing heat integration will lessen the potency of ozone layer depletion.

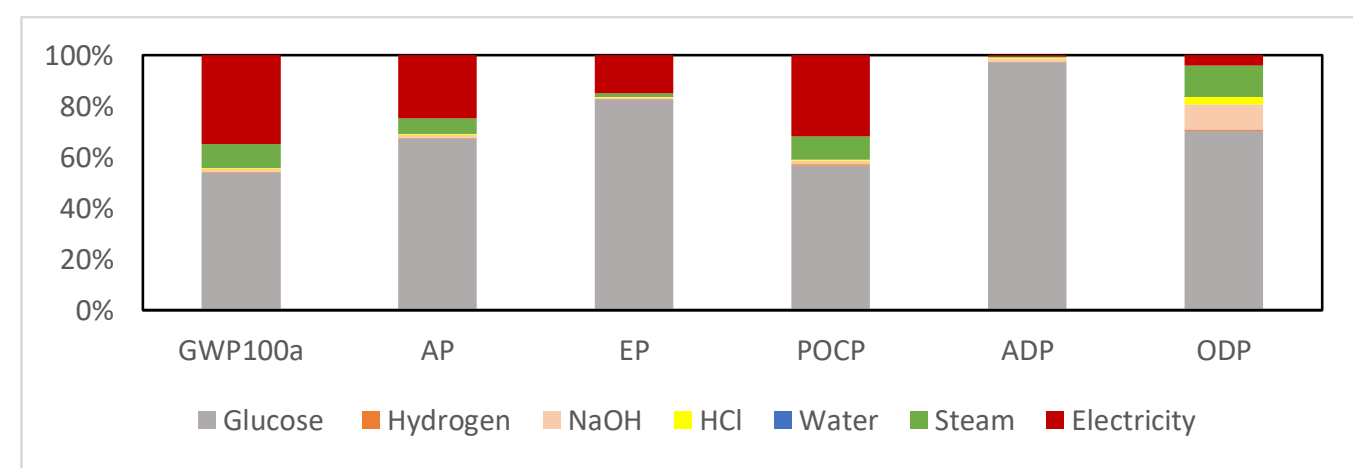

Figure 2. Contribution of the processes to the potency of environmental impact 


\section{Conclusion}

A gate-to-gate LCA study of sorbitol has shown that global warming or GHG emission has a great potential to affect the environment, while the others (acidification, eutrophication, photochemical oxidants creation, abiotic depletion, and ozone layer depletion) have a lower impact to the environment. The use of glucose as a raw material is known as the greatest contributor for each impact category because of its preparation and production process. Electricity consumption also gives a significant impact on GWP besides glucose usage, in which the highest electricity demand is from the hydrogenation reactor.

Reducing the impact value of GWP is possible by performing the improvement in the glucose production process, but this study is limited only on the gate-to-gate system. Therefore, it is important to do further assessment that including glucose preparation and processing in the system boundary (cradle-to-gate system). For more comprehensive LCA study, the production process of sorbitol can be modified, particularly in term of heat integration to reduce energy demand. Generally, this LCA study is completing the other studies of sweetener production. In addition, it is also advantageous to perform more sustainable improvement of sorbitol processing, and hopefully, it can also be used as a starting point on commercial production of sorbitol.

\section{Acknowledgement}

This paper was supported by Rendra Hakim Hafyan, a master student of chemical engineering, Universiti Teknologi Petronas.

\section{References}

An, V., and Katrien, B. (2015). Life Cycle Assessment study of starch products for the European starch industry association (Starch Europe): sector study (Belgium).

Baumann, H., and Rydberg, T. (1994). Life cycle assessment: A comparison of three methods for impact analysis and evaluation. J. Clean. Prod. 2, 13-20.

Fiorentino, G., Ripa, M., Mellino, S., Fahd, S., and Ulgiati, S. (2014). Life cycle assessment of Brassica carinata biomass conversion to bioenergy and platform chemicals. J. Clean. Prod. 66, 174-187.
Food Insight (2009). Sugar Alcohols Fact Sheet.

Gerbrandt, K. (2014). The Impacts of Xylitol Production from Hemicellulose Residues: Process Design, Life Cycle, and TechnoEconomic Assessment. University of Toronto.

Gerbrant, K.L. (2014). The Impacts of Xylitol Production from Hemicellulose Residues: Process Design, Life Cycle, and TechnoEconomic Assessment. University of Toronto.

Guinee, J.B. (2006). Handbook on life cycle assessment operational guide to the ISO standards (Dordrecht: Kluwer Academic Publishers).

Hafyan, R., Bhullar, L., Putra, Z., Bilad, M., Wirzal, M., and Nordin, N. (2019). Sustainability assessment of xylitol production from empty fruit bunch. MATEC Web Conf. 268, 06018 .

Lestari, R.L., Bohez, E.L.J., Ciptomulyono, U., and Perret, S.R. (2013). Life Cycle Assessment of Sugar from Sugarcane: A Case Study of Indonesia. ASEANAsian Acad. Soc. Int. Conf. Proceeding Ser. 17-20.

Marques, C., Tarek, R., Sara, M., and Brar, S.K. (2016). Sorbitol Production From Biomass and Its Global Market. In Platform Chemical Biorefinery, (Elsevier), pp. 217-227.

Mohammed, A.-H.A.K., Barbooti, M.M., and Ahmed, M.J. (2002). D-Sorbitol Production by Catalytic Hydrogenation of D-Glucose. Iraq $\mathbf{J}$. Chem. Pet. Eng. 3, 1-5.

Ochoa-Gómez, J.R., and Roncal, T. (2017). Production of Sorbitol from Biomass. In Production of Platform Chemicals from Sustainable Resources, Z. Fang, R.L. Smith, and X. Qi, eds. (Singapore: Springer Singapore), pp. 265-309.

Peters, J.F., Iribarren, D., and Dufour, J. (2015). Simulation and life cycle assessment of biofuel production via fast pyrolysis and hydroupgrading. Fuel 139, 441-456.

Renouf, M.A., Wegener, M.K., and Nielsen, L.K. (2008). An environmental life cycle assessment comparing Australian sugarcane with US corn and UK sugar beet as producers of sugars for fermentation. Biomass Bioenergy 32, 11441155.

Silveira, M.M., and Jonas, R. (2002). The biotechnological production of sorbitol. Appl. Microbiol. Biotechnol. 59, 400-408. 